\title{
MECHANISM OF 3,4-DIHYDROXYBENZALDEHYDE ELECTROPOLYMERIZATION AT CARBON PASTE ELECTRODES - CATALYTIC DETECTION OF NADH
}

\author{
Maria Flávia Delbem, Wilhelm Josef Baader and Sílvia Helena Pires Serrano* \\ Instituto de Química, Universidade de São Paulo, Av. Professsor Lineu Prestes, 748, 05508-900 São Paulo - SP
}

Recebido em 26/5/01; aceito em 20/12/01

\begin{abstract}
Cyclic voltammetry was used to study 3,4-dihydroxybenzaldehyde (3,4-DHB) electropolymerization processes on carbon paste electrodes. The characteristics of the electropolymerized films were highly dependent on $\mathrm{pH}$, anodic switching potential, scan rate, 3,4-DHB concentrations and number of cycles. Film stability was determined in citrate/phosphate buffer solutions at the same $\mathrm{pH}$ used during the electropolymerization process. The best conditions to prepare carbon paste modified electrodes were $\mathrm{pH} 7.8 ; 0.0 \leq \mathrm{E}_{\text {apl }} \leq 0.25 \mathrm{~V} ; 10 \mathrm{mV} \mathrm{s}^{-1} ; 0.25 \mathrm{mmol} \mathrm{L}^{-1} 3,4-\mathrm{DHB}$ and 10 scans. These carbon paste modified electrodes were used for NADH catalytic detection at $0.23 \mathrm{~V}$ in the range $0.015 \leq[\mathrm{NADH}] \leq 0.21 \mathrm{mmol} \mathrm{L}^{-1}$. Experimental data were used to propose a mechanism for the 3,4-DHB electropolymerization processes, which involves initial phenoxyl radical formation.
\end{abstract}

Keywords: 3,4-dihydroxybenzaldehyde; electropolymerization process; chemically modified electrode; cyclic voltammetry; NADH electrocatalytic oxidation.

\section{INTRODUCTION}

The $\beta$ - nicotinamide adenine dinucleotide co-factor (NADH) is necessary to the catalytic action of more than 300 different $\mathrm{NAD}^{+} / \mathrm{NADH}$ dependent dehydrogenases. Electrochemical oxidation of NADH is particularly important because several non electroactive substrates can be indirectly determined if one of the catalytic reaction products is electroactive, which is the case of NADH. Reviews describing redox and catalytic electrooxidation process of NADH have been published ${ }^{1,2}$

Unfortunately, oxidation of this coenzyme at a bare electrode occurs at high overpotentials and depends on the history of the electrode surface $^{3-6}$. Electrode poisoning has been also reported ${ }^{4,5,7,8}$ and partially solved using the electrochemical pre-treatment procedure described by Blaedel and Jenkins ${ }^{3,4}$. Besides good reproducibility of the results, those authors observed a curvature in log-log current applied potential plots for potentials higher than $0.9 \mathrm{~V}$ and small decreases in currents across the transport limited region for replicate scans within a day by using steady-state voltammetry. These experimental observations were attributed to an eventual instability of NADH in phosphate buffer solution ${ }^{9}$ and are also indicative of electrode poisoning.

Experiments performed with nicotinamide mononucleotide $\left(\mathrm{NMN}^{+}\right)$and its reduction product, $\mathrm{NMNH}$, without adenine in the molecule, showed that adsorption on the electrode surfaces decreased ${ }^{10}$. These results are in good agreement with those reporting strong adsorption of guanine and adenine at glassy carbon electrodes $^{11,12}$. At $\mathrm{pH} 7.0$, oxidation of adenine occurs at $0.9 \mathrm{~V}$ $(v s \mathrm{SCE})^{13}$ and a strong adsorption of the oxidation products has been reported ${ }^{14}$. From this viewpoint, the curvature in log-log current applied potential plots ${ }^{4}$ could be due to oxidation of free adenine, coming from NADH - phosphate adducts decomposition'.

In fact, electrochemical oxidation of NADH at a bare glassy carbon electrode was observed to be dependent on the supporting electrolyte composition. Adducts between phosphate anions and nicotinamide and adenosine groups in the NADH molecule are formed and catalyze the cofactor decomposition producing free adenine. The

*e-mail:shps@quim.iq.usp.br latter is oxidized above $0.9 \mathrm{~V}$ ( $v s \mathrm{Ag} / \mathrm{AgCl}, \mathrm{KCl}$ sat) and its oxidation products, adsorbed on the electrode surface, blocked further NADH oxidation $^{15}$. The best buffer used for NADH determination was piperazine - N, N'- bis [2-ethanesulfonic acid], $\mathrm{pH} 6.8^{15}$.

The adsorption and electrochemical oxidation of NADH were studied at carbon ${ }^{16-18}$ and platinum electrodes ${ }^{17,19}$. When carbon and platinum surfaces were previously covered with $\mathrm{NAD}^{+}$, peak potentials for NADH oxidation did not change; oxidation currents varied linearly with $\mathrm{NADH}$ concentrations and the last one was determined in micromolar range ${ }^{16-17}$. These results showed that $\mathrm{NAD}^{+}$ also adsorbs on electrode surfaces, but the adsorbed layer allows NADH oxidation.

Several studies on electrocatalytic oxidation of NADH using chemically modified electrodes were reported since early 80 's $\mathrm{s}^{20-44}$. Modified electrodes with 3,4- dihydroxybenzaldehyde and related analogs have been described ${ }^{37-40,42}$ and used to develop new ${ }^{39,42-44}$ aldehyde and alcohol biosensors. The best procedure to prepare modified electrodes was using constant applied potentials ${ }^{37,39,43}$.

Mechanisms for 3,4-DHB electropolymerization processes involving phenoxyl radical formation with further dimerization process on the electrode surface ${ }^{37}$, oxidation to the correspondent quinone with subsequent nucleophil-c attack from active functional groups on the electrode surface ${ }^{40,44}$ and chain propagation of 3,4-DHB through the aldehyde functionality ${ }^{45}$ have been proposed, but they do not suggest possible pathways for electropolymerization processes and film growing. Additionally, the appearance of a reversible redox pair at potentials lower than those necessary to oxidize 3,4-DHB molecules is still unknown.

In this work cyclic voltammetry was used to prepare 3,4 - DHB modified carbon paste electrodes with catalytic properties for NADH oxidation. The best conditions to prepare 3,4 - DHB modified carbon paste electrodes such as temperature, $\mathrm{pH}$, anodic switching potential, scan rate, cycle numbers and 3,4-DHB concentrations are presented.

Carbon paste electrodes were chosen because cofactor and/or enzymes could be previously introduced in the carbon paste composition or immobilized during the electropolymerization process, which occurs at low applied potentials, insuring the integrity of the biological components and avoiding its lixiviation. 


\section{EXPERIMENTAL}

\section{Chemicals and solutions}

$\beta$-NADH, disodium salt (Cat. No 124644); NADPH, tetrasodium salt (Cat. No. 124540); sodium nitrate (Cat. No. 106537); sodium hydroxide (Cat No. 106495); sodium monohydrogen phosphate (Cat. No. 106586) and citric acid (Cat. No 100241) were supplied from Merck (Rio de Janeiro, Brazil). Piperazine-N,N'-bis[2-ethanesulphonic acid] (PIPES) (Cat. No. 5625-37-6) was supplied by Alfa AESAR; 3,4-dihydroxybenzaldehyde (3,4-DHB) (Cat. No. D10.8405) and nujol oil (Cat. No. 16140-3) were supplied by Aldrich Chemical Co.; graphite was Acheson 38 from Fisher. All reagents were used without previous purification.

Buffer solutions were prepared as described previously ${ }^{46}$. Stock solutions of $\beta$-NADH, NADPH and 3,4-DHB were prepared by dissolution of the salt in buffer solution just before the experiments. All solutions were prepared with purified water from a Barnstead Nanopure system.

\section{Apparatus}

All electrochemical measurements were performed using a PGSTAT 20 potentiostat/galvanostat, controlled by GPES version 4.3 from Eco Chemie, Utrecht, Netherlands. $\mathrm{pH}$ measurements were carried out using a $\mathrm{pH}$ meter model 654 with a combined glass electrode, both from Metrohm.

\section{Electrode system and experimental procedures}

The working electrode was carbon paste, $\mathrm{A}=0.070 \mathrm{~cm}^{2}$, prepared with graphite/nujol in 2:1 proportion; counter and reference electrodes were $\mathrm{Pt}$ wire and a miniaturized $\mathrm{Ag} / \mathrm{AgCl}$ (sat. $\mathrm{KCl}$ ) electrode ${ }^{47}$, respectively, all placed in a one-compartment cell.

The electrodes were pretreated in $1.0 \mathrm{~mol} \mathrm{~L}^{-1} \mathrm{NaOH}$ solution and the working electrode potential was held at $+1.20 \mathrm{~V}$ for $5 \mathrm{~min}$, followed by 6 scans from -0.20 to $1.0 \mathrm{~V}$ in buffer solution, as described by Pariente et al. ${ }^{37}$. Afterwards the electrodes were rinsed with deionized water and modified in citric acid/ $\mathrm{Na}_{2} \mathrm{HPO}_{4}(\mathrm{pH} 2.6 ; 3.6$; $4.6 ; 6.6 ; 7.8)$ and $10.2\left(\mathrm{NaHCO}_{3} / \mathrm{NaOH}\right)$ buffer solutions containing $0.5 \mathrm{mmol} \mathrm{L} \mathrm{L}^{-1} 3,4-\mathrm{DHB}$ (at $\sim 12^{\circ} \mathrm{C}$ ) cycling the potential between -0.2 and $1.0 \mathrm{~V}$. Two oxidation peaks $\left(\mathrm{E}_{\mathrm{p}, \mathrm{a} 1}\right.$ and $\mathrm{E}_{\mathrm{p}, \mathrm{a} 2}$ ) and two reduction peaks $\left(\mathrm{E}_{\mathrm{p}, \mathrm{c} 1}\right.$ and $\left.\mathrm{E}_{\mathrm{p}, \mathrm{c} 2}\right)$ were observed, which were used to limit the scan range. The electrodes were modified within the limits $\left(\mathrm{E}_{\mathrm{p}, \mathrm{c} 1}-0.15 \mathrm{~V}\right)$ and $\left(\mathrm{E}_{\mathrm{p}, \mathrm{a} 2}+0.15 \mathrm{~V}\right)$ at $50 \mathrm{mV} \mathrm{s}^{-1}$ for 10 cycles.

Amperometric detections of NADH were performed at $0.23 \mathrm{~V}$ in an electrochemical cell containing $10.0 \mathrm{~mL}$ of supporting electrolyte (PIPES buffer, $\mathrm{pH}$ 6.8) where several additions of $3.0 \mathrm{mmol} \mathrm{L}^{-1}$ of $\mathrm{NADH}$ and NADPH stock solutions (prepared in the same supporting electrolyte) were made to obtain the desired analyte concentration.

\section{RESULTS AND DISCUSSION}

\section{Influence of pH on 3,4-DHB electropolymerization process}

Since 3,4-DHB has quinone/hydroxyl functionalities, it would be expected that the electropolymerization reaction should be $\mathrm{pH}$ dependent. The influence of $\mathrm{pH}$ on the electropolymerization process was studied modifying the carbon paste electrodes in $0.5 \mathrm{mmol} \mathrm{L}^{-1}$ 3,4 -DHB solutions at various $\mathrm{pH}$ values $(2.6 ; 3.6 ; 4.6 ; 6.6 ; 7.8$ and 10.2) using cyclic voltammetry and 10 scans at $50 \mathrm{mV} \mathrm{s}^{-1}$.

Figure 1 shows that during the first anodic scan, only one sharp anodic peak $\left(\mathrm{E}_{\mathrm{p}, \mathrm{a} 2}\right)$ appeared. Upon reversing scan direction, two small

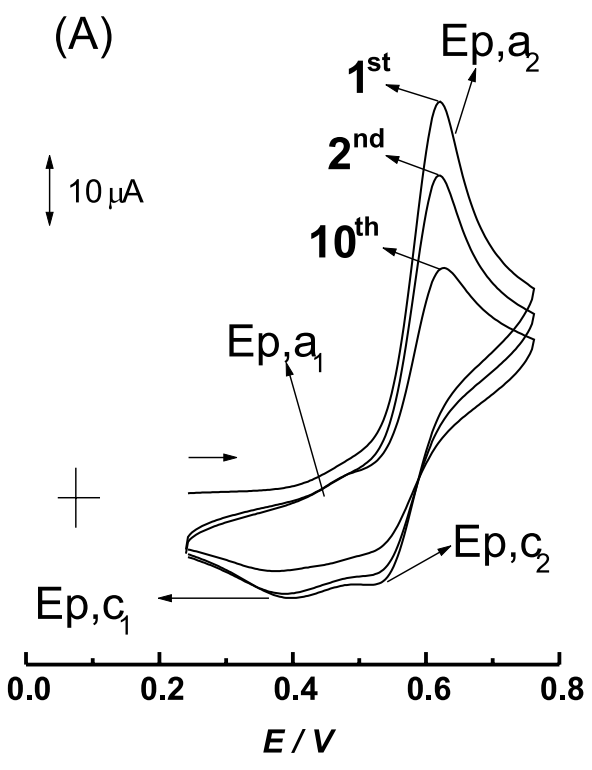

(B)

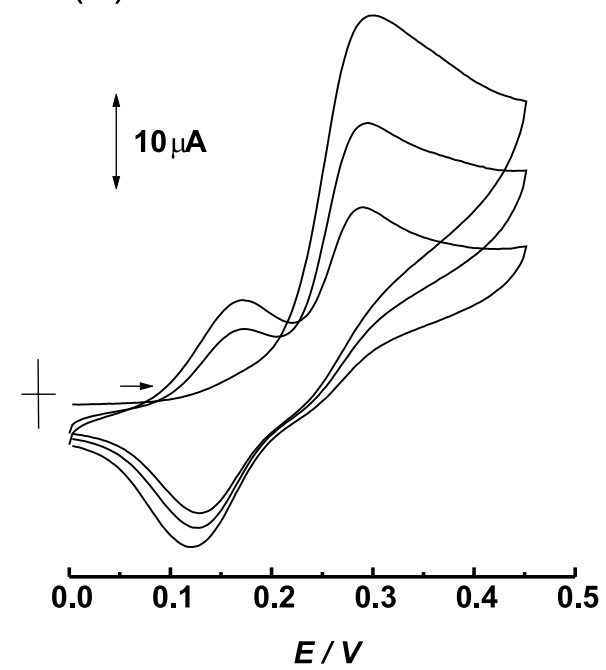

(C)

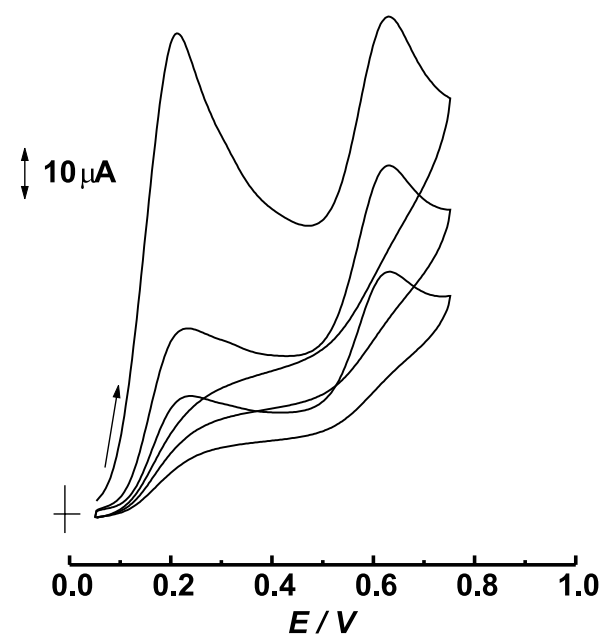

Figure 1. Cyclic voltammograms $\left(1^{\text {st. }}, 2^{\text {nd }}\right.$ and $\left.10^{\text {th }}\right)$ recorded for $0.5 \mathrm{mmol} \mathrm{L^{-1 }}$ 3,4-DHB in different $p H$ values: (A) $p H 2.6$; (B) $p H 7.8$ and (C) $p H 10.2$ at carbon paste electrode. Experimental conditions: $\left(E p, c_{1}-0.15 \mathrm{~V}\right) \leq E_{a p l} \leq\left(E p, a_{2}+0.15 \mathrm{~V}\right), 50 \mathrm{mVs}^{-1}$ and 10 scans 
cathodic waves were observed $\left(\mathrm{E}_{\mathrm{p}, \mathrm{c} 1}\right.$, and $\left.\mathrm{E}_{\mathrm{p}, \mathrm{c} 2}\right)$ and with successive potential scanning, an additional anodic peak was observed $\left(\mathrm{E}_{\mathrm{p}, \mathrm{a} 1}\right)$. On increasing $\mathrm{pH}$, the second cathodic peak $\left(\mathrm{E}_{\mathrm{p}, \mathrm{c} 2}\right)$ disappeared and, at the same time, a better definition of the reversible pair $\left(\mathrm{E}_{\mathrm{p}, \mathrm{al}} / \mathrm{E}_{\mathrm{p}, \mathrm{cl}}\right)$ was obtained (Figure 1a-1b). Additionally, with continued potential cycling, the reversible peak current increased (film growth), while the current of the second anodic peak decreased. However, at $\mathrm{pH}$ 10.2 only two irreversible peaks were recorded (Figure 1c).

The 3,4-DHB modified electrodes were rinsed with deionized water and placed in buffer solution at the same $\mathrm{pH}$ used during the electropolymerization process. Using the same potential range and scan rate, only the reversible peaks were recorded and at $\mathrm{pH} 10.2$ there was no evidence for film formation (Figure $2 \mathrm{a}-2 \mathrm{c}$ ).

At $\mathrm{pH}$ values between 2.6 and 7.8 the anodic and cathodic peak potentials for the reversible pair changed linearly with $\mathrm{pH}^{37,40,48}$, according to the equations: $\mathrm{E}_{\mathrm{p}, \mathrm{a}}=0.65-0.064 \mathrm{pH}\left(\mathrm{r}^{2}=0.9995\right)$ and $\mathrm{E}_{\mathrm{p}, \mathrm{cl}}=0.61-0.064 \mathrm{pH}\left(\mathrm{r}^{2}=0.9997\right)$.

During successive cycles in supporting electrolyte, the current peaks decreased, probably due to film inactivation as consequence of secondary reactions or desorption of species weakly bound to the electrode surface. The percentage of active film loss for $n$ scans was determined, considering the peak current for the second cycle as $100 \%$ and reporting the current peak for $\mathrm{n}$ cycles (Table 1). Taking into account higher current levels and lower loss of active film percentage, the best $\mathrm{pH}$ for growing films was found to be 7.8 .

\section{Influence of anodic switching potential, scan rate, number cycles and 3,4-DHB concentrations on the stability of 3,4-DHB electropolymerized films}

Considering that a second oxidation peak $\left(\mathrm{E}_{\mathrm{p}, \mathrm{a} 2}\right)$ was recorded only during film formation (Figure 1) vanishing in supporting electrolyte (Figure 2), it was clear that the product formed at $\mathrm{E}_{\mathrm{p}, \mathrm{a} 2}$ did not adsorb on the electrode surface. These results indicated that it was necessary to verify whether the applied potential (corresponding to $\mathrm{E}_{\mathrm{p}, \mathrm{a} 2}$ ) had some influence on film formation and its further stability in supporting electrolyte.

Films were formed in $0.0 \leq \mathrm{E}_{\text {apl }} \leq 0.45 \mathrm{~V}$ and $0.0 \leq \mathrm{E}_{\text {apl }} \leq 0.25 \mathrm{~V}$ ranges $(\mathrm{pH} 7.8)$ and stability tests were carried out in supporting electrolyte, at the same $\mathrm{pH}$ and potential ranges. The highest current (anodic and cathodic) and smallest loss of active film were obtained for films formed in the range $0.0 \leq \mathrm{E}_{\mathrm{apl}} \leq 0.25 \mathrm{~V}$, with stability tests performed in the same potential range. In this case, loss of active film dropped to $9 \%$ (for $\mathrm{I}_{\mathrm{p}, \mathrm{al}}$ ) and $8 \%$ (for $\mathrm{I}_{\mathrm{p}, \mathrm{cl}}$ ) after 20 scans. When film formation and stability tests were carried out in the range $0.0 \leq \mathrm{E}_{\text {apl }} \leq 0.45 \mathrm{~V}$, loss of active film increased to $15 \%$ (for $\mathrm{I}_{\mathrm{p}, \mathrm{al}}$ ) and $18 \%$ (for $\mathrm{I}_{\mathrm{p}, \mathrm{c}}$ ) after 20 scans. These data showed that to get films with higher stability, the anodic switching potential should not go beyond $0.25 \mathrm{~V}$ (for $\mathrm{pH} 7.8$ ). Fast and complete loss of the surfaceimmobilized material was observed when the potential was cycled to potentials more positive than $0.4 \mathrm{~V}(\mathrm{pH} \mathrm{7.0})^{37}$. According to our

Table 1. Loss active film percentage calculated for the tenth cycle recorded in supporting electrolyte (citrate/phosphate buffer solutions)

\begin{tabular}{ccc}
\hline $\mathrm{pH}$ & $\begin{array}{c}\text { \% of lost active film } \\
\left(\mathrm{Ip}, \mathrm{a}_{1}\right)\end{array}$ & $\begin{array}{c}\% \text { of lost active film } \\
\left(\mathrm{Ip}, \mathrm{c}_{1}\right)\end{array}$ \\
\hline 2.6 & 12 & 14 \\
3.6 & 18 & 16 \\
4.6 & 11 & 12 \\
6.6 & 19 & 21 \\
7.8 & 10 & 12 \\
\hline
\end{tabular}

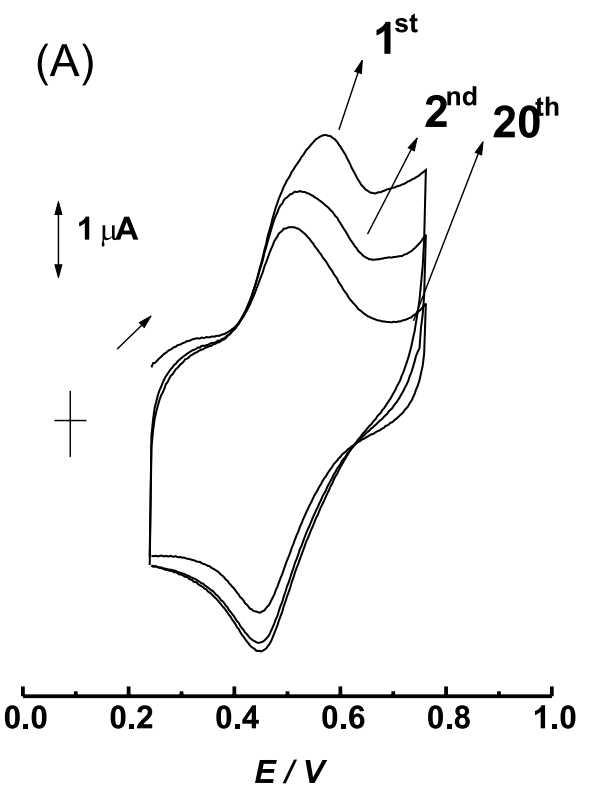

(B)
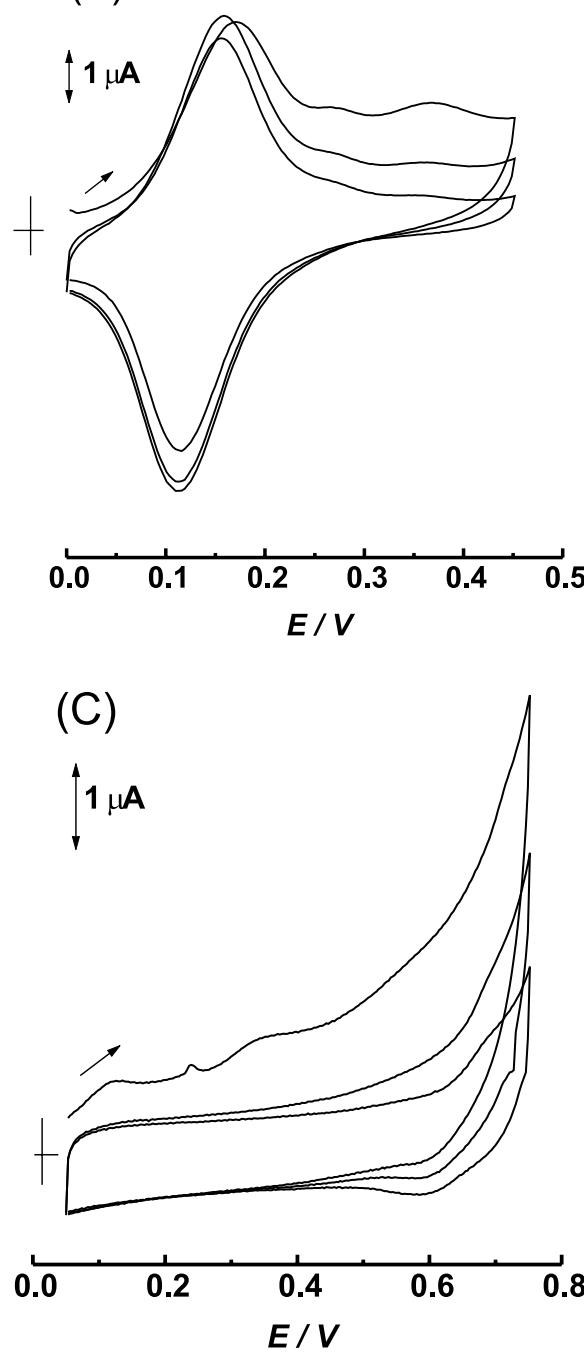

Figure 2. Cyclic voltammograms $\left(1^{\text {st }}, 2^{\text {nd }}\right.$ and $\left.10^{\text {th }}\right)$ recorded with 3,4-DHB modified carbon paste electrode in supporting electrolyte solution (citrate acid/Na $\mathrm{HPO}_{4}$ ) with the same $\mathrm{pH}$ and composition used for the film formation: (A) $p H$ 2.6; (B) $p H 7.8$ and (C) $p H$ 10.2. Experimental conditions: $\left(E p, c_{1}-0.15 \mathrm{~V}\right) \leq E_{a p} \leq\left(E p, a_{2}+0.15 \mathrm{~V}\right), 50 \mathrm{mV} \mathrm{s} \mathrm{s}^{-1}$ and 10 scans 
results, this potential corresponds to the second 3,4 - DHB oxidation peak, responsible for destruction of the electropolymerized film.

It is necessary to emphasize that this potential limit depends on the $\mathrm{pH}$ of the solution used during film formation and stability tests.

Electropolymerized films were prepared using 5; 10; 25; 50; 75 and $100 \mathrm{mVs}^{-1}$ and $5,10,15$ or 20 cycles in $0.5 \mathrm{mmol} \mathrm{L}^{-1} 3,4-\mathrm{DHB}$. Stability measurements were performed in supporting electrolyte at $50 \mathrm{mV} \mathrm{s}^{-1}$. Films with better stability were obtained using $10 \mathrm{mV} \mathrm{s}^{-1}$ and 10 cycles.

The last parameter to be studied was 3,4-DHB concentrations. Films were formed using $0.25,0.56,0.90$ and $1.8 \mathrm{mmol} \mathrm{L}^{-1}$ of 3,4-DHB. Increasing 3,4-DHB concentrations, thicker films should be formed, since higher current peaks were obtained. Peak current differences, recorded in supporting electrolyte, between the second and the $20^{\text {th }}$ cycle were lower for films formed with $0.25 \mathrm{mmol} \mathrm{L}^{-1}$ of 3,4-DHB. It seems that films obtained at lower 3,4-DHB concentration have better stability.

The best conditions to prepare 3,4-DHB electropolymerized carbon paste modified electrodes were: $\mathrm{pH} 7.8 ; 0.0 \leq \mathrm{E}_{\text {apl }} \leq 0.25 \mathrm{~V}$ potential range; $10 \mathrm{mV} \mathrm{s}^{-1}, 0.25 \mathrm{mmol} \mathrm{L}^{-1}$ of 3,4-DHB and 10 cycles.

\section{Mechanism involved in chain propagation of 3,4-DHB at carbon paste electrode surfaces}

The mechanism of 3,4 - DHB electropolymerization has been considered as similar to the one suggested by Hapiot et al. ${ }^{50}$ for oxidative dimerization of phenolic aldehydes by pulse radiolysis, which proposes dimerization of phenoxyl radicals. It was proposed because the oxidation peak potential of phenolic aldehydes changed linearly with the logarithm of the scan rate in the range $0.05 \leq \mathrm{v} \leq 20 \mathrm{~V} \mathrm{~s}^{-1}$, with a slope of $\sim 20 \mathrm{mV}$ and a peak width of $\sim 41 \mathrm{mV}$. These observations are consistent with a rate-determining coupling of two radicals formed from a fast electron transfer to a dimer, with $19.7 \mathrm{mV}$ slope for the plots $\partial \mathrm{Ep} / \partial \log (\mathrm{v})$. However, in our work the peak potential did not change upon increasing scan rate up to $100 \mathrm{mVs}^{-1}$. Additional studies have been done $\mathrm{e}^{40,44}$ and the oxidation of 3,4-DHB to the correspondent quinone, with a subsequent nucleophilic attack from active functional groups from the electrode surface, was then considered.

Gao et al. ${ }^{45}$ proposed a mechanism where chain propagation of 3,4-DHB polymerization involves the aldehyde functionality, but in benzaldehyde solution only a totally irreversible wave was observed at $1.80 \mathrm{~V}^{37}$. No evidence for a polymerization process involving these groups was obtained. In fact when benzaldehyde solution was changed for buffer solutions, only background current was observed over the range -0.20 to $+0.50 \mathrm{~V}$.

Our results are compatible with a mechanism in which phenoxyl radical formation is the first step of the 3,4-DHB electropolymerization process, similarly to anodic oxidation of phenols, where the initial anodic reaction involves an one electron oxidation to form free phenoxyl radicals ${ }^{51-58}$. Coupling reactions between these phenoxyl radicals in acidic conditions yield non electroactive dimeric products or long chain polymeric products, which are electroactive and more easily oxidizable than phenol ${ }^{55,56}$. Dimeric or long chain polymeric products produced by phenoxyl coupling reactions during 3,4-DHB electropolymerization can be discarded because electroactive films with good stability were obtained only at $\mathrm{pH}$ 7.8. Phenoxyl oxidation to produce monocations, which undergo reactions with phenol molecules, occurring in neutral or alkaline medium to produce long chain polymeric non electroactive structures, can be also discarded $^{55,56}$. In this way, an addition reaction between a phenoxyl radical and a 3,4-DHB molecule was considered as the most probable mechanism for the formation of 3,4 - DHB films (Figure 3).
FIRST CYCLIC VOLTAMMOGRAM

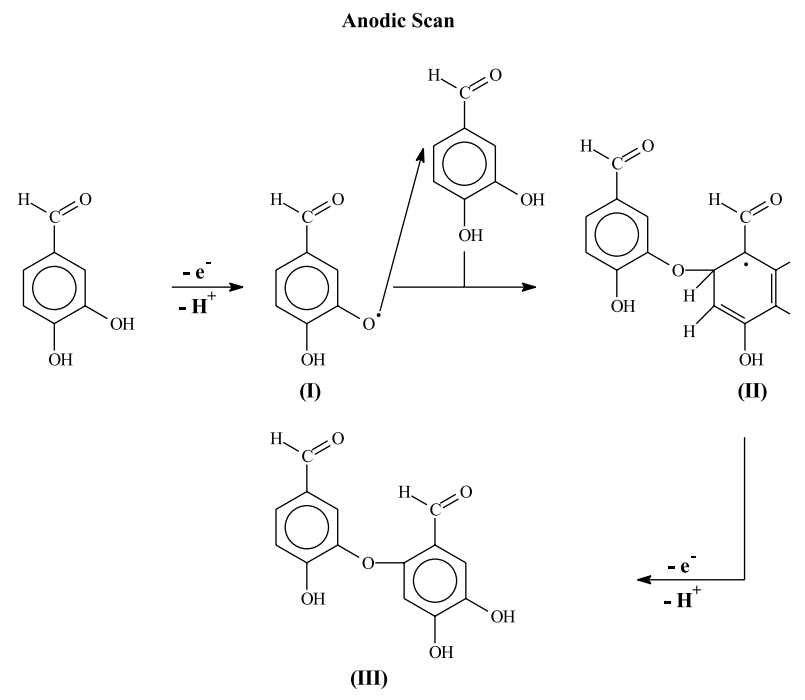

Cathodic Scan

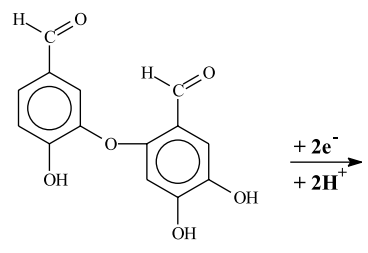

(III)

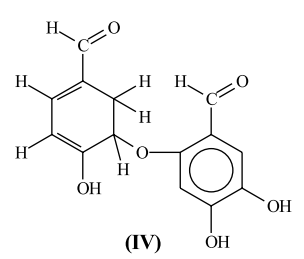

SECOND CYCLIC VOLTAMMOGRAM Anodic Scan

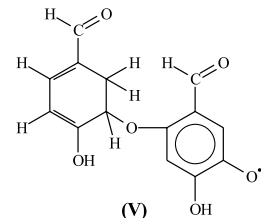

(V)

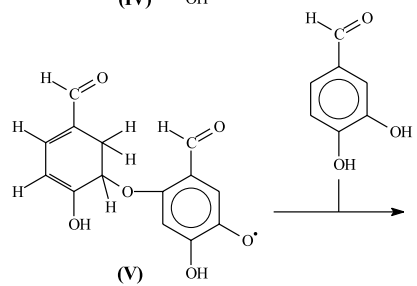

(V)
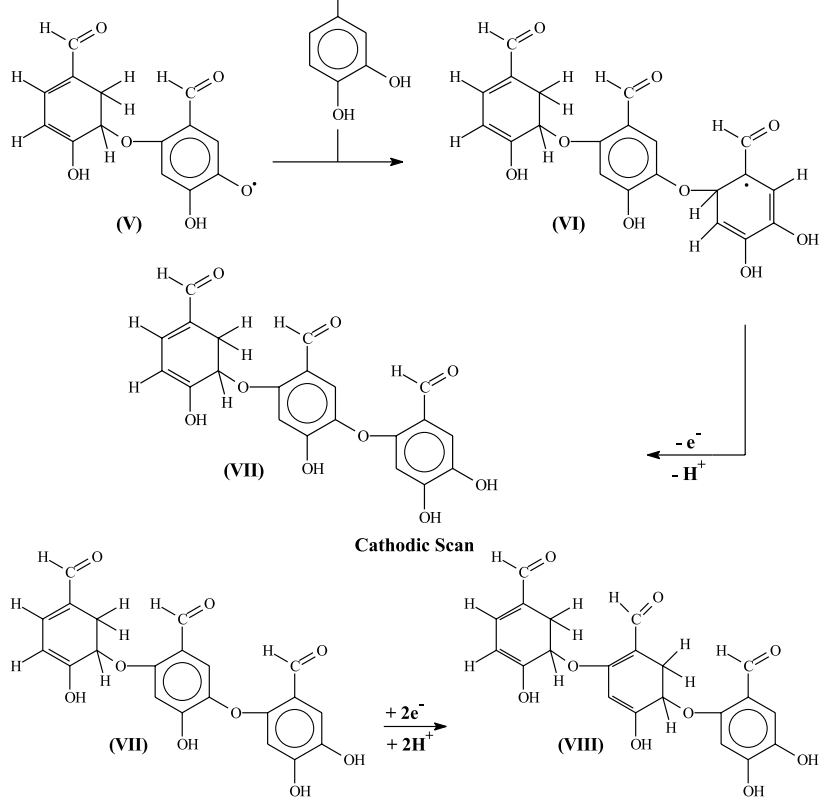

Figure 3. Mechanism proposed for chain propagation of 3,4-DHB at carbon paste electrode surface 
During the first anodic scan, a 3,4-DHB molecule may loose one proton and one electron, to produce a phenoxyl radical, (I). No peak corresponding to this process was recorded, probably because the radical should be formed only in the initial stage of the second 3,4DHB-oxidation process. In this mechanism, formation of phenoxyl radical was considered on the hydroxyl group bonded to $\mathrm{C}$ (3), but it could also be formed on the group attached to $C(4)$. The phenoxyl radical, I, attacks another 3,4-DHB molecule producing a new radical II, which is oxidized to compound III in a step involving another proton and electron. During the reverse sweep, compound III is reduced to compound IV at $0.13 \mathrm{~V}$ in a step involving 2 protons and 2 electrons ( $\mathrm{E}_{\mathrm{p}, \mathrm{cl}}$ - Figure 1B).

During the next anodic sweep, compound IV, in a step involving one proton and one electron, is re-oxidized to radical $\mathrm{V}$ at lower potentials $(0.18 \mathrm{~V})$ than the original 3,4-DHB molecules (compare $1^{\text {st }}$ cycle with $2^{\text {nd }}$ or $10^{\text {th }}$ cycle in Figure $1 \mathrm{~B}$ ), because IV contains one more oxygen bonded to the aromatic ring, which should provide additional stabilization to the phenoxyl radical, V. Radical V attacks another 3,4-DHB molecule to produce compound VI, which is oxidized to compound VII in a further step involving one electron and one proton. During the reverse sweep, VII is reduced to compound VIII and two protons and two electrons are involved in the process. Continuous cycling will to aggregate 4 or more $3,4-\mathrm{DHB}$ units of general structure VIII.

The anodic and cathodic peaks, recorded in supporting electrolyte, correspond to the VII/VIII reversible redox pair or another compound with similar structure.

The proposed mechanism explains why the best $\mathrm{pH}$ for film formation and stability tests was 7.8: in acidic medium, phenolic groups are not ionized and phenoxyl radical formation is more difficult, occurring at higher oxidation potentials. At $\mathrm{pH} 10.2$ film formation is inhibited, probably because the aldehyde group in 3,4-DHB molecules can be transformed to the respective hydrate, which is oxidized in an irreversible process.

At potentials corresponding to the second anodic oxidation process of 3,4-DHB $\left(\mathrm{E}_{\mathrm{p}, \mathrm{a} 2}\right)$ compounds III and VII can be further oxidized to form the respective quinone derivatives, in competition with oxidation of 3,4-DHB molecules which reach the electrode surface by diffusion. In the last case, film growing is stopped or a disordered surface layer, which is not stable during the potential sweeps in supporting electrolyte, is produced.

The film can be attached to the electrode surface by initial adsorption of free phenoxyl radicals ${ }^{52,53}$ or through one of the tautomeric structures of compound IV (Figure 4). Alternatively immobilization of the film on the electrode surface by active species as proposed in the literature ${ }^{40,44}$, is also possible.

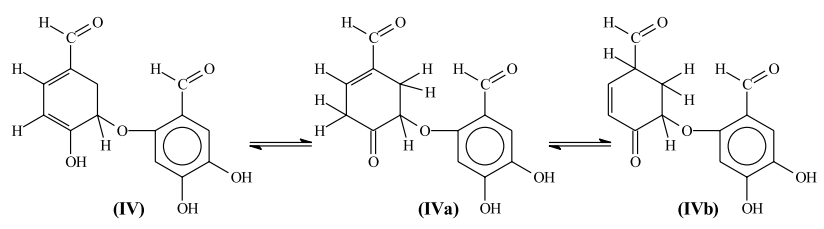

Figure 4. Tautomeric forms of structure IV

In order to have some experimental support, at least for the initial step of the proposed electropolymerization process, we tried to modify the carbon paste electrodes in $0.025 \mathrm{mmol} \mathrm{L}^{-1} 3,4$-DHB solutions containing $0.60 \mathrm{mmol} \mathrm{L}^{-1}$ of $\mathrm{NAD}(\mathrm{P}) \mathrm{H}$, a known phenoxyl radical scavenger in biological systems ${ }^{59}$. Figure 5 shows the voltammograms

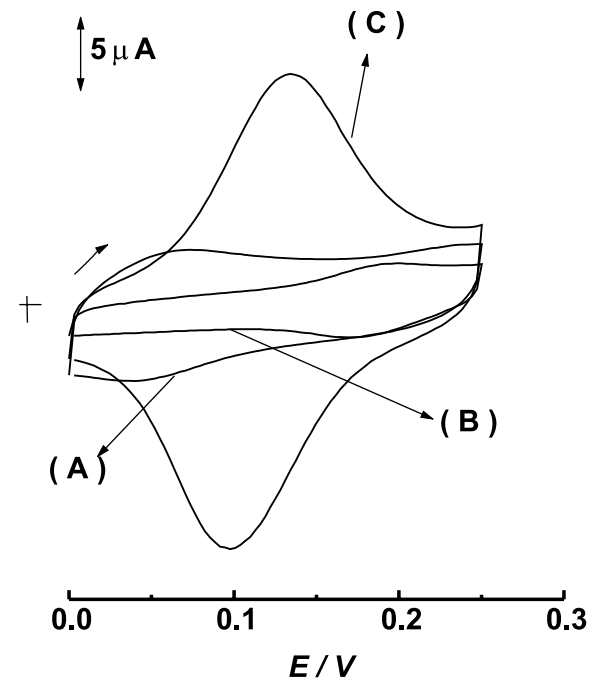

Figure 5. Cyclic voltammogram recorded in supporting electrolyte with the carbon paste electrode after modification in: (A) $0.25 \mathrm{mmol} \mathrm{L}^{-1} 3,4-\mathrm{DHB}$ containing $0.60 \mathrm{mmol} \mathrm{L}^{-1}$ of NADPH solution; (B) $0.25 \mathrm{mmol} \mathrm{L} \mathrm{L}^{-1} 3,4-\mathrm{DHB}$ containing $0.60 \mathrm{mmol} \mathrm{L}^{-1}$ of $\mathrm{NADH}$ solution and $(\boldsymbol{C})$ carbon paste electrode modified in $0.25 \mathrm{mmol} \mathrm{L}^{-1} 3,4-\mathrm{DHB}$ solution

carried out in supporting electrolyte after electropolymerization in 3,4-DHB solutions contained NADPH or NADH. As it can be seen, the electropolymerization process was totally inhibited in the presence of NADPH and partially inhibited in the presence of NADH.

These results are a strong indication that phenoxyl free radical formation may be the first step in the electropolymerization process and show that it is not possible to immobilize cofactors (NADH or NADPH) during the growing of 3,4-DHB electropolymerized films. Enzyme immobilization can be also difficult because enzymatic activity may decrease as a consequence of enzyme/free radical reactions.

The inhibition of film formation in the presence of NADPH cannot be attributed to an eventual previous cofactor adsorption on the electrode surface. When the electrode was pre treated in 0.60 mmol L-1 NADPH and further placed in 3,4-DHB solutions, the film was formed as usually observed in 3,4 - DHB solutions.

If these considerations are true, lower scan rates should favor film growth and its immobilization at the electrode surface, while production of higher concentrations of phenoxyl radicals could lead to highly disordered low chain length films, which are not well adsorbed at the electrode surface.

At $0.23 \mathrm{~V}$, potential used for catalytic detection of $\mathrm{NADH}$ and $\mathrm{NADPH}$, the analyte can react with C (2) of the aromatic ring in VII, for example, or with a phenoxyl radical formed in this potential. In both cases, the reduced film can be electrochemically re-oxidized at the electrode surface and the anodic current is proportional to NADH concentration in solution.

\section{Electrochemistry of electropolymerized 3,4-DHB films}

As can been seen from Figures 1 (B) and 2 (B), the redox behavior of 3,4-DHB electropolymerized films in supporting electrolyte is a reversible process. For linear sweep and cyclic voltammograms the parameter $\left|\mathrm{E}_{\mathrm{p}}-\mathrm{E}_{\mathrm{p} / 2}\right|$ is one of several diagnostic criteria for reversible systems and corresponds to $2.2 \mathrm{RT} / \mathrm{nF}$ or $0.0566 / \mathrm{n} \mathrm{V}$ (at $25^{\circ} \mathrm{C}$ ), where $\mathrm{R}$ is the gas constant, $\mathrm{T}$ the temperature in Kelvin, $\mathrm{F}$ the Faraday constant and $\mathrm{n}$ the number of electrons involved in the electrochemical 
process $^{49}$. For films formed under optimized conditions, the parameter $\left|\mathrm{E}_{\mathrm{p}}-\mathrm{E}_{\mathrm{p} / 2}\right|$, obtained from voltammograms recorded in supporting electrolyte (buffer phosphate, $\mathrm{pH} 7.8$ ) at $50 \mathrm{mV} \mathrm{s}^{-1}$, was $0.030 \mathrm{~V}$. This means that the number of electrons involved in the electrochemical process is 2 .

Since $\Delta \mathrm{Ep} / \Delta \mathrm{pH}$ was 0.064 for both anodic and cathodic process, the number of protons involved is also 2 . This was calculated using the equation $\Delta \mathrm{Ep} / \Delta \mathrm{pH}=0.0592 \mathrm{p} / \mathrm{n}$ for the reversible process ${ }^{48}$, where $\mathrm{p}$ and $\mathrm{n}$ are the numbers of protons and electrons respectively.

At $\mathrm{pH} 7.8, \mathrm{Em}\left(\mathrm{E}_{\mathrm{p}, \mathrm{cl}}+\mathrm{E}_{\mathrm{p}, \mathrm{al}} / 2\right)$ corresponded to $0.12 \mathrm{~V}$ vs $\mathrm{Ag} / \mathrm{AgCl}$ (sat. $\mathrm{KCl}$ ). The modifier surface excess was $8 \times 10^{-10}$ $\mathrm{mol} \mathrm{cm}{ }^{-2}$, calculated using by the anodic charge obtained from cyclic voltammograms (obtained in supporting electrolyte, $\mathrm{pH} 7.8$, $\mathrm{v}=50 \mathrm{mV} \mathrm{s}^{-1}$ ), after subtraction of the background charge, utilizing the relation: $\Gamma=\int(\mathrm{idt} / \mathrm{nFA})=\mathrm{Q} / \mathrm{nFA}$, where $\mathrm{Q}$ is the charge in coulombs and $\mathrm{A}$ the electrode area in $\mathrm{cm}^{2}$.

\section{Amperometric detection of NADH}

The catalytic NADH oxidation by electropolymerized 3,4-DHB films can be represented by the scheme:

$\mathrm{NADH}+$ Film $_{(\mathrm{ox})} \rightarrow \mathrm{NAD}^{+}+$Film $_{(\text {red })}($ chemical step $)$

Film ${ }_{\text {(red) }} \rightarrow$ Film $_{(\mathrm{ox})}+2 \mathrm{e}^{-}$(electrochemical step monitored at the electrode)

According to this, the cathodic current should decrease as a function of successive additions of $\mathrm{NAD}(\mathrm{P}) \mathrm{H}$ to a supporting electrolyte, as it was experimentally observed. Amperometric $\mathrm{NAD}(\mathrm{P}) \mathrm{H}$ determinations were performed at $0.23 \mathrm{~V}$. However, only in NADPH solutions the modified surface was quickly lost after the first analytical curve. This result is in accordance with data shown in Figure 5.

The same procedure was used with NADH and the analytical curve is shown in Figure 6. As it can be seen, about $25 \mathrm{~s}$ were necessary to get an amperometric stable response. The linear concentration range was $0.015 \leq[\mathrm{NADH}] \leq 0.21 \mathrm{mmol} \mathrm{L}^{-1}$; Ip $(\mu \mathrm{A})=(32.5 \pm 0.3)[\mathrm{NADH}]+(0.0505 \pm 0.0001)[\mathrm{n}=9$, $\left.\mathrm{r}^{2}=0.9983\right]$ and the detection limit estimated was $1.2 \times 10^{-2} \mathrm{mmol} \mathrm{L}^{-160}$. The surface was active for catalytic NADH oxidation during three days when the modified electrode was kept in phosphate buffer, $\mathrm{pH} 7.8$.

\section{CONCLUSIONS}

Cyclic voltammetry was used to prepare 3,4-DHB electropolymerized films on carbon paste electrodes. The characteristics of these films were highly dependent on $\mathrm{pH}$, anodic switching potential, scan rates, 3,4-DHB concentrations and number of the potential cycles utilized. The best conditions to prepare modified carbon paste electrodes were $\mathrm{pH} 7.8 ; 0.0 \leq \mathrm{E}_{\mathrm{apl}} \leq 0.25 \mathrm{~V} ; 10 \mathrm{mV} \mathrm{s}^{-1}$; $0.25 \mathrm{mmol} \mathrm{L}^{-1} 3,4-\mathrm{DHB}$ and 10 scans. The modified electrodes could be used for amperometric NADH determinations with linear response in the range $0.015 \mathrm{mmol} \mathrm{L}^{-1} \leq[\mathrm{NADH}] \leq 0.21 \mathrm{mmol} \mathrm{L}^{-1}$, during three days at $0.23 \mathrm{~V}$ (vs $\mathrm{Ag} / \mathrm{AgCl}, \mathrm{KCl}$, sat). However, the lifetime of these modified electrodes was considerably smaller if they were used for catalytic determination of NADPH.

The electropolymerization process was totally inhibited in the presence of NADPH and partially inhibited in the presence of NADH. Since NADPH is a known phenoxyl radical scavenger in biological systems, phenoxyl free radical could be the species responsible for the initial step of the electropolymerization process. It is not possible
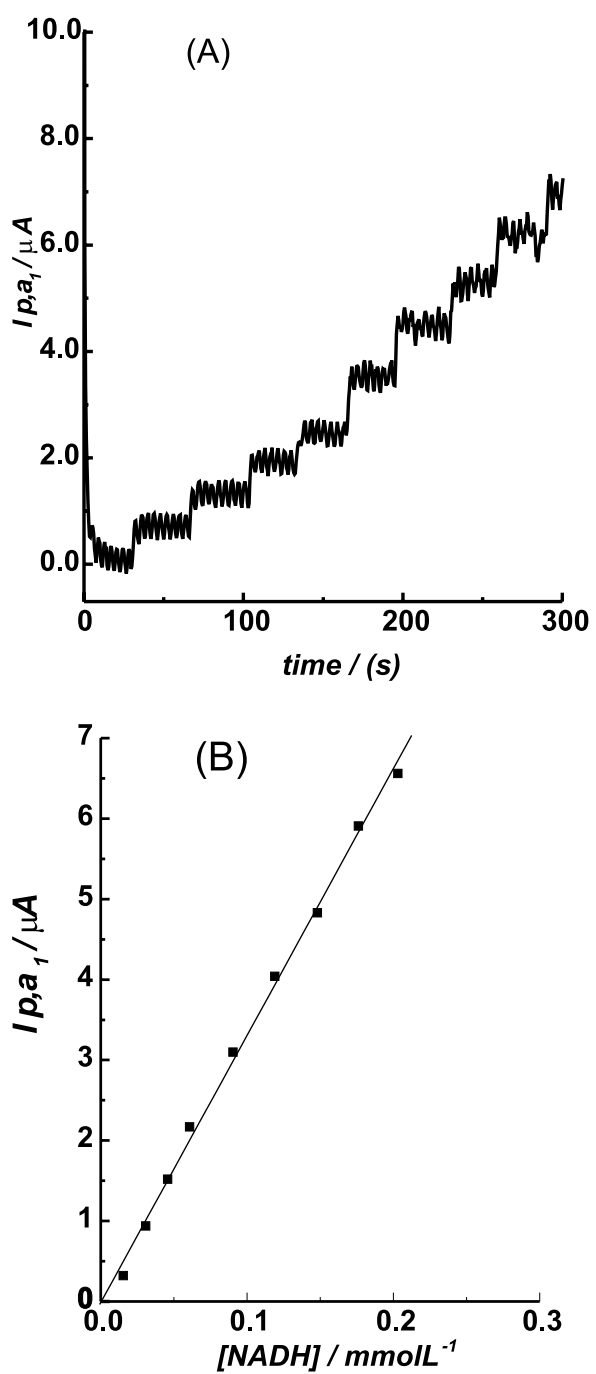

Figure 6. (A) Amperogram recorded with 3,4-DHB carbon paste modified electrode (optimised conditions) in PIPES buffer ( $p H$ 6.8) containing $0.15 \leq[N A D H] \leq 0.21 \mathrm{mmol}^{-1}$ and $(\boldsymbol{B}) \mathrm{NADH}$ analytical curve

to immobilize cofactors (NADH or NADPH) during the growing of 3,4-DHB electropolymerized films, because $\mathrm{NAD}(\mathrm{P}) \mathrm{H}$ can act as free radical scavenger. Enzyme immobilization can be also difficult because enzymatic activity can be affected by free radicals.

\section{ACKNOWLEDGEMENTS}

M. F. Delbem thanks FAPESP for a fellowship; we thank FAPESP and CNPq for financial support and Drs. L. Angnes, P. C. Isolani and Paulo T. A. Sumodjo for helpful suggestions.

\section{REFERENCES}

1. Elving, P. J.; Schmakel; C. O.; Santhanam, K. S. V.; CRC-Crit. Rev. in Anal. Chem. 1976, 6, 1 .

2. Katakis, I.; Dominguez, E.; Mikrochim. Acta 1997, 126, 11.

3. Blaedel, W. J.; Jenkins, R. A.; Anal. Chem. 1974, 46, 1952.

4. Blaedel; W. J.; Jenkins; R. A.; Anal. Chem. 1975, 47, 1337.

5. Aizawa, M.; Coughlin, R.W.; Charles, M.; Biochim. Biophys. Acta 1975, $385,362$.

6. Braun, R. D.; Santhanam, K. S. V.; Elving, P. J.; J. Am. Chem. Soc. 1975, 97, 2591.

7. Burnett, J. N.; Underwood, L.; Biochemistry 1965, 4, 2060.

8. Leduc P.; Thévenot, D.; J. Electroanal. Chem. 1973, 47, 543. 
9. Alivisatos, S.G.A.; Ungar, F.; Abraham, G.; Nature 1964, 203, 973.

10. Samec, Z.; Elving, P. J.; J. Electroanal. Chem. 1983, 144, 217.

11. Brett, C.M.A.; Brett, A. M. O.; Serrano, S.H.P.; J. Electroanal. Chem. 1994, 366,225 .

12. Moiroux, J.; Elving, P.J.; J. Electroanal. Chem. 1979, 102, 93.

13. Dryhurst, G.; Talanta 1972, 19, 769.

14. Dryhurst, G.; Elving, P. J.; J. Electroanal. Chem. 1968, 115, 1014.

15. Katekawa, E.; Maximiano, F.; Rodrigues, L.L.; Delbem, M.F.; Serrano, S.H.P.; Anal. Chim. Acta 1999, 385, 345.

16. Moiroux, J.; Elving, P. J.; Anal. Chem. 1978, 50, 1056.

17. Moiroux, J.; Elving, P. J.; Anal. Chem. 1979, 51, 346.

18. Blankespoor, R.L.; Miller, L.; J. Electroanal. Chem. 1984, 171, 231.

19. Jaegfeldt, H.; J. Electroanal. Chem. 1980, 110, 295

20. Torstensson, A.; Gorton, L.; J. Electroanal. Chem. 1981, 130, 199.

21. Gorton, L.; J. Chem.Soc. Faraday Trans. 1986, 1, 1245

22. Persson, B.; J. Electroanal. Chem. 1990, 287, 61.

23. Persson, B.; Gorton, L.; J. Electroanal. Chem. 1990, 292, 115.

24. Wu, Q.; Maskus, M.; Pariente, F.; Tobalina, F.; Fernández, V.M.; Lorenzo, E.; Abruña, H. D.; Anal. Chem. 1996, 68, 3688.

25. Chi, Q.; Dong, S.; Electroanalysis 1995, 7, 147

26. Nagy, G.; Kapui, I.; Gorton, L.; Anal. Chim. Acta 1995, 305, 65

27. Rubinson, J.F.; Neff, S.; Mark Jr., H.B.; Galal, A.; Atta, N. F.; J. Electroanal. Chem. 1995, 384, 19.

28. Angnes, L.; Azevedo, C.M.N.; Araki, K.; Toma, H.E.; Anal. Chim. Acto 1996, 329, 91.

29. Lobo, M.J.; Miranda, A.J.; López-Fonseca, J. M.; Tuñon, P.; Anal. Chim. Acta 1996, 325, 33

30. Zhou, D.; Fang, H-Q.; Chen, H.; Ju, H.; Wang, Y.; Anal. Chim. Acta 1996, $329,41$.

31. Huan, Z.; Persson, B.; Gorton, L.; Sahni, S.; Skotheim, T.; Bartlett, P.; Electroanalysis 1996, 8, 575.

32. Ohtami, M.; Kuwabata, S.; Yoneyama, H.; J Electroanal. Chem. 1997, 422, 45

33. Cai, C.-X.; Xue, K.-H.; J. Electroanal. Chem. 1997, 427, 147.

34. Pessoa, C.A.; Gushiken, Y.; Kubota, L.; Gorton, L.; J. Electroanal. Chem. 1997, 431, 23.

35. Bartlett, P.N.; Birkin, P.R.; Wallace, E.N.K.; J. Chem. Soc. Faraday Trans. 1997, 93, 1951 .
36. Cai, C.-X.; Xue, K.-H.; Anal. Chim. Acta 1997, 343, 69.

37. Pariente, F.; Lorenzo, E.; Abruña, H.D.; Anal. Chem. 1994, 66, 4337.

38. Lorenzo, E.; Sánchez, L.; Pariente, F.; Tirado, J.; Abruña, H. D.; Anal. Chim. Acta 1995, 309, 79.

39. Pariente, F.; Lorenzo, E.; Tobalina, F.; Abruña, H. D.; Anal. Chem. 1995, 67, 3936.

40. Pariente, F.; Tobalina, F.; Darder, M.; Lorenzo, E.; Abruña, H. D.; Anal. Chem. 1996, 68, 3135

41. Pamidi, P.V.A.; Wang, J.; Electroanalysis 1996, 8, 244.

42. Pariente, F.; Tobalina, F.; Moreno, G.; Hermández, L.; Lorenzo, E.; Abruña, H.D.; Anal. Chem. 1997, 69, 4065

43. Tobalina, F.; Pariente, F.; Hermández, L.; Abruña, H.D.; Lorenzo, E.; Anal. Chim. Acta 1998, 358, 15.

44. Lorenzo, E.; Pariente, F.; Hermández, L.; Tobalina, F.; Darder, M.; Wu, Q.; Maskus, M.; Abruña, H.D.; Biosens. Bioelectron. 1998, 13, 319.

45. Gao, Z.; Siow, K. S.; Ng, A.; Zang, Y.; Anal. Chim. Acta 1997, 343, 49.

46. Perrin, D.D.; Dempsey, B.; Buffer for $\mathrm{pH}$ and Metal Ion Control, Science Paperback, Chapman and Hall: London, 1983, p. 151,153.

47. Pedrotti, J.J.; Angnes, L.; Gutz, I. G. R.; Electroanalysis 1996, 8, 673.

48. Zummann, P. In The Elucidation of Organic Electrodes Processes; Meites, L., ed.; Academic Press: London, 1969, p. 120.

49. Brett, C.M.A.; Brett, A.M.O.; Electrochemisty, Principles, Methods and Applications, Oxford University Press: Oxford, 1993, p. 180.

50. Hapiot, P.; Pinson, J.; Francesch, C.; Mhamdi, F.; Rolando, C.; Neta, P.; J. Phys. Chem. 1994, 98, 2641.

51. Hedenburg, J. F.; Freiser, H.; Anal. Chem. 1953, 25, 1355.

52. Zeigerson, E.; Gileadi, E.; J. Electroanal. Chem. 1970, 28, 421.

53. Bejerano, T.; Forgaes, Ch.; Gileadi, E.; J. Electroanal. Chem. 1970, 27, 69.

54. Koile, R. C.; Johnson, D. C.; Anal. Chem. 1979, 51, 741.

55. Sharma, L. R.; Singh, G.; Sharma, A.; Indian J. Chem. 1986, 25A, 345.

56. Sharma, L. R.; Singh, G.; Sharma, A.; Indian J. Chem. 1989, 28A, 757.

57. Wang, J.; Li, R.; Anal. Chem. 1989, 61, 2809.

58. Mafatle, T.; Nyokong, T.; Anal. Chim. Acta 1997, 354, 307.

59. Goldman, R.; Tsyrlov, I. B.; Grogan, J.; Kagan, V. E.; Biochemistry 1997, $36,3186$.

60. Miller, J. C.; Miller, J. N.; Statistics for Analytical Chemistry, Ellis Horwood: UK, 1998, p. 115. 